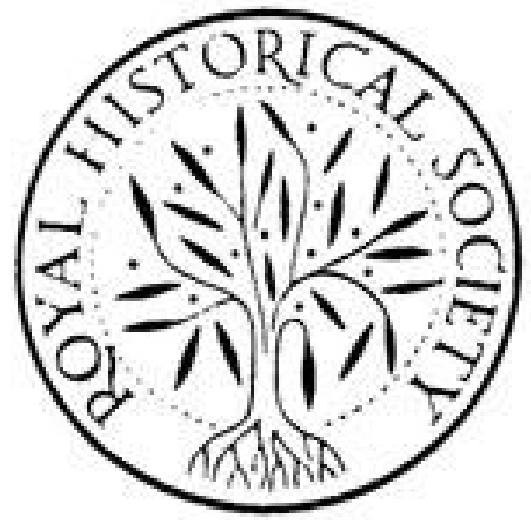

An Outline History of the Hanseatic League, More Particularly in Its Bearings upon English Commerce Author(s): Cornelius Walford

Source: Transactions of the Royal Historical Society, Vol. 9 (1881), pp. 82-136 Published by: Cambridge University Press on behalf of the Royal Historical Society Stable URL: http://www.jstor.org/stable/3677937

Accessed: 27-06-2016 11:35 UTC

Your use of the JSTOR archive indicates your acceptance of the Terms \& Conditions of Use, available at http://about.jstor.org/terms

JSTOR is a not-for-profit service that helps scholars, researchers, and students discover, use, and build upon a wide range of content in a trusted digital archive. We use information technology and tools to increase productivity and facilitate new forms of scholarship. For more information about JSTOR, please contact support@jstor.org.

Cambridge University Press, Royal Historical Society are collaborating with JSTOR to digitize, preserve and extend access to Transactions of the Royal Historical Society 


\section{AN OUTLINE HISTORY OF THE HANSEATIC LEAGUE, MORE PARTICULARLY IN ITS BEARINGS UPON ENGLISH COMMERCE.}

By Cornelius Walford, F.I.A., F.S.S., F.R.Hist.Soc.

[Read before Royal Historical Society, 19th Feb., 1880.]

IN calling the attention of the fellows to some of the leading points in the history of one of the most remarkable confederations which the world has ever seen, and in endeavouring to arrange these into an harmonious and intelligent narrative, I feel that I owe no apology, except at least to the extent to which my labours may be found deficient or defective : for it is in the direction of such original inquiries as the present that our Society may perform its more useful offices. England played a most prominent part in the history of the Hanseatic League; but in this regard has found heretofore no historian, while Germany has several. Hence the present attempt, the results of which, gathered from many sources, are presented without further preface.

\section{EARLY TRADING COMMUNITIES IN LONDON.}

London, Eighth CENTURY.-Even at this date-that is, under the Saxon rule-there is believed to have been communities of strangers settled in London for the purposes of commerce; but from whence they came has not been accurately determined.-Trans. of London and Midx. Archaological Society, iii., p. 67.

The Cologne merchants were soon after this period established in Dowgate, and they made complaints of their privileges being interfered with by later traders who had arrived [see 1234]. And mention is made in the early 
records of this country, at varying dates, of Germans, Teutons, Almains, Garpar, and Vandals. Further specific mention of some of these will occur as we proceed. English merchants at this, or a slightly later period, had "factories" on the Baltic coast as far as Prussia, and in the dominions of Denmark.

979. At about this date-time of Ethelred II.-a body of German traders, understood to be really an Order of Monks long engaged alternately in commerce and in warfare, had established themselves in London, and had met with Royal patronage. They are spoken of in the old chronicles as coming with many ships to Billingsgate, and in return for some slight presents and tolls were deemed worthy of extraordinary privileges, which were continued by succeeding monarchs.

\section{MERCHANTS OF THE "STEELYARD."}

It is probably as far back as this period that we must look for the establishment of the Merchants of the "Steelyard "a name, perhaps, but slightly corrupted from its original meaning of the stiliard or beam for weighing goods imported into London-sometimes called the "King's Beam." It was natural that those who were largely engaged in commerce, particularly in bulky merchandise, should establish themselves near to the spot whereon such an operation was conducted. But when the "tonnage" was transferred to the Corporation of London, the king's beam was removed-some authorities say to Cornhill-but certainly, at a later date to Weigh-house Yard, at Little Eastcheap, which was at this time probably by the river. The king's beam being removed, the Merchants of the Steelyard most likely took possession of the entire spot; and there established their factory. This famous location lay between Thames-street and the river. It was of considerable extent; and at one period protected with high and strong walls, and probably fortified. Several centuries later it became known as the Gilhalda Tutonicorum-the Guildhall of the Germans. 
These early "steelyard" merchants (confirming their monastic origin) conducted their affairs with the utmost secrecy, and lived personally in a state of entire seclusion, like the inmates of a monastery. Indeed, the Steelyard was a monastery-the only difference being that its brotherhood were devoted to money-making instead of religious exercises. The vast buildings on the river-side, in the parts not used for storage, were divided into separate cells for single men-the whole of the ranges opening into common reception-rooms. No inmate of the Steelyard was allowed to marry, or even to visit any person of the opposite sex, and a breach of this law, however slight, was followed by immediate expulsion, if not by more severe penalties. At a fixed hour every evening all the brothers were expected to be at home; the gates were then rigidly closed; and at a certain hour in the morning, varying with the seasons, were open again for the transaction of business. When we come to speak more directly of the Hanseatic League we shall see that many of these regulations were in conformity with their practice.

These early trading monks established themselves in other cities than London, as we have very abundant evidence in the ordinances of the Great Gild of St. John of Beverley of the Hanshouse, whereof the introduction is as follows :-

"Thurston, by the Grace of God, Archbishop of York, to all the faithful in Christ, as well now as hereafter, greeting, and God's blessing, and his own. Be it known to you that I have given and granted, and with the advice of this Chapter of York and Beverley and of my barons, have by my Charter confirmed to the men of Beverley all liberties, with the same laws that the men of York have in their city. Moreover, be it not unknown to you that the Lord Henry our King [Henry I.] has, with a good will, granted to us the power of making [this charter], and has, by his own charter, confirmed our statutes and our laws, after the manner of the laws of the Burgesses of York, saving what behoves to God and St. John, and myself and the canons; that so he might uphold and enlarge the honour of the alms-deeds of his predecessors. With all these free customs I will that my Bourgesses of Beverley shall have their 'Hanshus;' which 
I give and grant to them in order that therein their common business may be done [ut ibi sua statuta pertractent] in honour of God and S. John and the canons, and for this amendment of the whole town with the same freedom that the men of York have in their 'Hanshus.' I also grant to them toll for ever, for xviij. marks a year; saving on the three feasts on which toll belongs to us and the canons-namely, on the feast of St. John the Confessor in May, and the feast of the Translation of St. John, and the Nativity of St. John the Baptist. On these three feasts I have made all the Burgesses of Beverley free and quit of every toll. This charter also bears witness that I have granted to the same burgesses free right of coming in and going out-namely, within the town and beyond the town, in plain and wood and marsh, in ways and paths and other easements, save in meadows and cornfields, as good, free, and large as anyone can grant and confirm. And know ye that they shall be free and quit of any toll all through the whole shire of York, like as the men of York are. And I will that whosoever gainsays this shall be accursed, as the manner of cursing is in the church of St. John, as shall be adjudged in the church of St. John. These are witnesses; Geoffry Mirdoc, Nigel Ffossard, Urnald Perci, Walter Spec, Eustace son of John, Thomas the provost, Thurstin the archdeacon, Herbert the canon, William the son of Tole, William of Bajus; before the household, both clergy and laity, of the Archbishop of York."

This charter was confirmed by the successor to Thurston.

\section{BALTIC CITIES.}

The first town erected on the coasts of the Baltic was Lubeck, which owes its foundation to Adolphus, Count of Holstein. After several vicissitudes it became independent of any sovereign but the emperor in the $13^{\text {th }}$ century. Hamburg and Bremen, upon the other side of the Cimbric peninsula, emulated the prosperity of Lubeck; the former city purchased independence of its Bishop in 1225. A colony from Bremen founded.Riga in Livonia, about I162. The city of Dantzic grew into importance about the end of the following century. Koningsberg was founded by Ottacar, King of Bohemia, in the same age. 


\section{FIRST INDICATIONS OF THE LEAGUE.}

But the real importance of these cities is to be dated from their famous union with the Hanseatic Confederacy. The origin of this is rather obscure; but it certainly may be nearly referred in point of time to the middle of the thirteenth century, and accounted for by the necessity of mutual defence, which piracy by sea, and pillage by land, had taught the merchants of Germany. The nobles endeavoured to obstruct the formation of this league, which, indeed, was in great measure designed to withstand their exactions. It powerfully maintained the influence which the free imperial cities were at this time acquiring. Eighty of the most considerable places constituted the Hanseatic Confederacy, divided into four colleges, whereof Lubeck, Cologne, Brunswick, and Dantzic, were the leading towns. Lubeck held the chief rank, and became, as it were, the patriarchal see of the League; whose province it was to preside in all general discussions for mercantile, political, or military purposes, and to carry them into execution. The League had four principal factories in foreign parts-at London, Bruges, Bergen, and Novogorod ; indorsed by the sovereigns of these cities with considerable privileges to which every merchant belonging to a Hanseatic town was entitled.

We shall have to review some of the later incidents in more detail; but the immediate purpose before us at this point being to fix the date of the origin of the League, we think we must now consider it as having really taken definite shape in the thirteenth, and not the preceding, century. This appears to conform to the views of the later historians of the League. The progress of the League is admitted to have been very slow during its first century.

We now resume our chronological narrative.

I 169. Oddy, in his "European Commerce" (London, I805), which contains a large body of facts connected with the history of the League, after stating (p. I I) that Lubeck was founded in II4O, and "very soon increased so as to 
become the first commercial city of the north of Germany owing to its convenient situation on the Baltic Sea," proceeds :

"The rapid prosperity of Lubeck excited both envy and emulation; and the envy soon was extended to all the towns that by their efforts to equal Lubeck became prosperous. Denmark and Sweden, Holstein and Saxony, by becoming enemies of those trading towns, forced them to enter into the Hanseatic League, of which Lubeck was from the beginning considered as the chief." . . .

It was about the year I I69, when the commercial cities of Julin and Winnet had been destroyed by the Danes and other pirates, and when Lubeck, Rostock, and other cities had received their dispersed inhabitants, that the Hanseatic Confederacy acquired force. The cities wished to protect themselves from a similar calamity. The first towns were Lubeck, Wismar, Rostock, Stralsund, Grypeswald, Ankam, Stettin, Colberg, Stolpe, Dantzic, Elbing, and Koningsberg. It was a standing rule of this League, that no city should be admitted into it that was not situated on the sea, or on a navigable river, and that did not keep the keys of its own gates. The cities must likewise have the civil jurisdiction in their own hands; but they were allowed to acknowledge a superior lord.

He adds :

"The policy of those trading republics at a time when war and chivalrous expedition were the occupation and glory of kings and princes could not but be productive of good. It was necessary to have some head, and they chose for their protectors the Grand Master and German Knights of the Cross, established in Prussia, who had made a conquest of Livonia.

" By this means the Hanse Towns commanded the commerce of the Baltic, from Denmark to the bottom of the Gulf of Finland, together with that of the rivers which run into that sea, from the interior of an extensive country, producing a vast variety of articles of great importance in the commerce of the world."

II70. The great confederacy of the Hanse Towns (commenced the year before) is confirmed. Twelve towns on the Baltic shore-“Lubec, Wismar, Rostoc, Straelsund, Grypes- 
wald, Anklam, Stedin, Colberg, Stolpe, Danzic, Elbing, and Konisberg," unite in a League for their mutual protection; they agree to hold a general assembly once every ten years in order to admit or exclude members, and to confirm the Association. They choose for their protectors the Master and Knights of the Teutonic Order; and admit the Teutonic towns in Prussia and Livonia to participate of their institution. By degrees many German and Flemish towns (seated on navigable rivers) are admitted to the League. Lubeck is allowed to take the lead.-Vide Andrews, quoted from Werdenhagen, "the prolix historian" of the League.

\section{ENGLISH PRIVILEGES TO FOREIGN MERCHANTS.}

1232. The English monarch Henry III. granted a charter of privileges to the merchants of the Steelyard at this date, the effect of which was to constitute them into a Trading Gild, after the manner of the period. This was for services they had done him beyond the seas. [Some German writers give the date at I206, but Henry III. did not ascend the throne until I2I6]. This charter was renewed by his son, Edward I. Stow, in his famous "Survey," under date I259, gives the following account of this Charter, which is important on points of identification :

1232. "Then to these merchants [of Almaine] . . . . Henry III. at the request of his brother Richard, Earl of Cornwall, King of Almaine [Germany], granted that all and singular the merchants having a house in the City of London, commonly called Guilda Aula Theutonicorum, should be maintained and upholden through the whole realm by all such freedoms and free usages, or liberties as by the king and his noble progenitors' time they had, and enjoyed," \&c.

There is preserved among the Harleian MSS. in the British Museum, a paper inscribed Grauntes of Privileges by Kings of England from Henry III. to King Edward IV., to the Haunces of the Steelyard, which shows the vast extent and importance of the immunities from tolls and other 
vexations which these escaped, and which it may be presumed, therefore, others had to bear!

That the "Easterlings"-a designation attached to the merchants from the more eastern shores of the Balticcarried on a considerable trade with London at this date, is generally recorded. They are said to have coined money in this reign, which on account of its goodness, was named after these merchants, but afterwards became corrupted into " Sterling," a word which is still significant in its meaning in all commercial matters.

I 234. Henry III. is reputed to have granted a charter to the merchants of Cologne then settled in London, this, the eighteenth year of his reign. Mention is made of these merchants as settled in London during the ninth century.

1257. Henry III. is said to have granted charters to the merchants of Lubeck, Brunswick and Denmark, settled in London, in this the forty-first year of his reign.

1269. The same monarch (Henry III.) granted a charter to the merchants of the Teutonic Guildhall, in this the fortyfourth year of his reign.

\section{HANSEATIC LEAGUE.}

1239. The actual establishment of the Hanseatic League is usually now attributed to this date-the name being derived from the old German Hansa, a union or confederacy. The League is said to have been limited to three cities only, in its inception, viz., to Hamburg, Ditmarsh, and Hameln. It is further recorded that the conditions of this early treaty were that this city of Hamburg should clear the country of vagabonds and robbers, between the river Trene and the city, and prevent pirates cruising on the Elbe as far as the ocean. This, however, seems such a purely local purpose that we cannot but think that some error is involved. As other discrepancies in date and circumstance exist, we propose to review the several conflicting authorities briefly.

124I. Macpherson, in his "Annals of Commerce," \&c., a work of known repute, says, it seems probable that the League 
derived its origin from an agreement which was entered into this year by the merchants of Hamburg and Lubeck, to establish a guard for the protection of their merchandise against pirates and robbers in the inland carriage between their cities. "A precaution very necessary in those days of rapine, when men of the first rank having no useful employment, or elegant amusement to relieve them from the languor of idleness in times of peace, openly professed the trade of robbery" (Vol. i. p. 393). He says in a note: "This is the date assumed by Lambecius, Struvius, Pfeffel, \&c., and surely the German writers, from local situation as well as industry in research are well qualified for the examination .of such a matter." But authorities differ, and certainly here there is much room for it.

1255. The Confederacy, under the name of the League of the Rhine, was sanctioned by the approbation of the Emperor William, and confirmed in a general assembly of his allies, held at Oppenheim. It was determined that assemblies be held once every three months, in order to deliberate on the interests of the League. The country soon experienced the good effect of this association; a count was hanged for violating the public peace, and the nobles desisted from robbing on the highway. The cities of Lubeck and Hamburg, already confederated for the protection of their commerce, do not seem to have had any connection with this association, which did not extend beyond the neighbourhood of the Rhine. But a coalition afterwards took place ; and the union of other small confederacies and single towns seems to have afterwards produced the powerful association of the Hanse, which (says Macpherson) "does not appear from any good authority to have existed at this time."- "Annals of Commerce," p. 405.

1262. Some German writers say that the Hanse Association about this time made choice of Bruges (in Flanders) to be a station for their trade, and an entrepot between the coasts of the Baltic and the Mediterranean-a voyage from one sea to the other and back again being too arduous an 
undertaking to be accomplished in one season. It is, moreover, said that the advantages of storage, commission, \&c., continued to enrich the inhabitants of Bruges, till the Emperor Frederick III. was provoked by an insult put upon his son to block up their port, whereby the Hanse merchants were obliged to transfer their commerce to Antwerp. Macpherson, however, still doubts whether the Hanse Association, under that name, was yet in existence; or if there were any maritime cities yet added to the confederacy entered into by Lubeck and Hamburg in the year I24I.

1270. We now discover in Norway the operations of the trading monks of North Germany whoobtained leavefrom the king to "fix the staple of their northern trade in the city of Bergen." At first their commerce was restricted to the summer months -from 3rd May to I4th September,-and the citizens were not allowed to let their houses to them for more than six weeks, to which, however, three were added for bringing in their goods, and three more for carrying out their returns. In process of time (says Macpherson) the Vandalic cities of Germany obtained permission to establish a permanent seat of their trade, called a contovi, in the city: and in consequence of that indulgence the bridge was covered with twenty-one large houses or factories, each of them capable of accommodating about a hundred merchants or factors, with their servants. They were bound to keep the houses and also the bridge in repair, and to perform watch and ward in that part of the city wherein they lived. The merchants were chiefly from Lubeck, Hamburg, Rostock, Bremen, and Deventer, and imported flax, cloth, corn, flour, biscuits, malt, ale, wine, spirituous liquors, copper, silver, \&c., and received in return butter, salmon, dried cod, fish-oil, fine furs, timber, \&c. They were obliged to confine their operations to Bergen, the trade of the rest of the country being reserved to the native merchants, to whom they gave credit of their goods till the ensuing season. By this commerce, while it continued in its most flourishing state, Bergen was so much enriched that no other city in the three northern kingdoms could be compared to it. 
The identity with the early trading monks who settled in London is made complete by a foot note, "They were all unmarried, and lived together in masses within their own factories." Among the early traders who settled in Bergen were those called Germans, Teutons, Almains, Garpar, Vandals, and at a later period Hansards or Hanseatics.

That great scholar, Sir Travers Twiss, Q.C., D.C.L., in his introduction to the fourth volume of the Black Book of the Admiralty [Master of the Rolls Series], I 876 (p. 1xxviii.), says :

"a political confederation, the origin probably does not date further back than A.D. I270; but the Great League zvas made up of minor associations, of which the most important in Western Germany had come into existence when the commercial cities on the Lower Rhine ranged themselves on the side of William, Count of Holland, who on the death of the Emperor Frederick II., in I 250 , disputed the Imperial crown with Conrad, the son of the late Emperor. Mayence was at first the centre of this association, which included the merchants and shipmasters of Friesland and of Holland; but Cologne subsequently became the headquarters of what may be appropriately described as the Rhenish branch of the Great Hanse League, which kept up its old headquarters as its departmental centre ; whilst Lubeck, Bergen, and Novgorod, became in a similar manner the departmental centres of the Saxon or Low German, the Scandinavian, and the Russian branches of the Great League respectively-Lubeck being, in addition, the great centre of the united League."

I280. Edward I. granted a charter to the merchants of the Teutonic Gildhall, which was, however, but a confirmation of the charter granted by his father in 1259. In this charter the term "Hanse" does not appear. But concerning this it need only be remarked that there was in truth no new organization in London. The "Hanseatic League" being formed in the north of Europe, it had appointed as its agents in London a body long established, and known under the title of the "Teutonic Merchants" or the "Gild of the Teutons ;" there was no object to be gained in assuming a 
new title: and, besides, in truth the German merchants resident in London never became part or parcel of the Confederation of the Hanseatic League (see 1314).

The King of Norway having refused the Hanse Towns a continuation of the privileges they had enjoyed in his ports, the League for the first time exerted its strength in a collective body; blocked up the ports of Norway, and compelled the king to renew their privileges, and make them a compensation in money. Oddy, p. I 5 .

I 282. This year (IO Edward I.) Henry Waleys Lord Mayor, a great controversy (says Stow) between the said mayor and the merchants of the Haunce of Almaine, about the reparations of Bishopsgate, then likely to fall; for that the said merchants enjoyed divers privileges in respect of maintaining the said gate, which they now denied to repair; for the appeasing of which controversy the king sent his writ to the Treasurer and Barons of his Exchequer, commanding that they should make inquisition thereof; before whom the merchants being called, when they were not able to discharge themselves, sith they enjoyed the liberties to them granted for the same, a precept was sent to the mayor and sheriff to distrain the said merchants to make reparations-namely, Gerard Marbod, Alderman of the Haunce, Ralph de Cusarde, a citizen of Culm, Tudero de Denevar, a burgess of Trivar, John of Aras, a burgess of Trivon, Bartram of Hamburdge, Godestalke of Hundondale, a burgess of Trivon, John de Dale, a burgess of Munstar, then remaining in the said city of London, for themselves, and all other merchants of the Haunce; and so they granted 210 marks to the mayor and citizens, and undertook that they and their successors should from time to time repair the said gate, and bear the third part of the charges in money and men to defend it when need were. And for this agreement the said mayor and citizens granted to the said merchants their liberties .... amongst others that they might lay up their grain which they brought into this realm in inns and sell it in their garners, by the space of forty days after they had laid it up, except by the mayor 


\section{TRANSACTIONS OF THE ROYAL HISTORICAL SOCIETY.}

and citizens they were expressly forbidden, because of dearth or other reasonable occasions.

I 284. The League was solemnly renewed at this date. It had been part of its original scheme to hold an extraordinary general assembly every ten years; admitting new members -i.e., Towns, and excluding old ones, if there were judged to be good reasons for doing so. We may here with advantage review the internal constitution of the League so far as may be necessary, in view of understanding points in its paternal history.

The confederacy was divided into four distinct classes, over each of which one city was to preside. At the head of the first division, as well as of the whole League, was Lubeck; here the general assemblies were to be held, the records, and the common stock, kept. Cologne was at the head of the second class; Brunswick was at the head of the third; Dantzic of the fourth class. Thus united, they were to support themselves against their common enemy; and thus united they certainly did procure the protection and friendship of many princes who would probably not have granted this to the individual cities. The Townes lying on the shores of the Baltic were termed Easterlings, and those towards the Rhine, of which Cologne was the chief, the Westerns, afterwards the Western Hanse Towns.

It has further to be noted that every Hanseatic citizen who, being resident in one of the factories abroad, there contracted marriage with a stranger, forfeited his political status as such. No merchant could enter into a commercial partnership with strangers. In the cities of the League sales could not take place between two persons, of whom neither was a member of the confederation, which law forced foreigners to employ the latter as intermediate agents in all matters of business they had to transact. Grain coming from the Elbe and the Vistula, could not be transported to other countries if it was not dispatched in a vessel cleared out from a city in League. And there were also several maritime regulations dictated by the same spirit of monopoly, and founded on an exclusive com- 
mercial system. Reddie's "Historical View of the Law of Maritime Commerce," p. 253.

The number of cities stated to have been in union at the commencement is sixty-two, but a complete list of these we have never seen. Of the many historians and writers upon the League, no two agree either as to number or names. This, however, may well be, from the circumstance of their all assuming different dates. That continual changes occurred is probable for many reasons. The towns which' became members of the confederation received the dignity of "Free Cities ;" perhaps, indeed, not in all cases-but the regulation in this regard we do not find. All cities in actual confederation had the right to trade freely with all other of the cities, as also with the great "factories" associated. The geographical constitution of the League at two other important periods in its history, I 364 and I476, will be given under those dates.

An able American writer, a few years since, gave the following outline of the position of the confederation at about this period :

"The League dictated to princes, raised troops, and made war against cities and states. The lords paramount who governed the Flemish and German provinces, being jealous of the authority of the League, often molested the Hanse Towns and went to war with them. The towns then appealed to the League, which, having forces much superior to those of any of the petty princes, peace was soon made, and the grievances of all under the protection of the League quickly redressed. So well convinced were the cities and towns of the advantage of such support, that the political and commercial relations of the Hanse became very extensive, and in a comparatively short time. All was not delightful in this compact, however, for many forms were necessary before relief could be obtained from the League, and it often came too late to be available. No city could declare war without the consent of the four nearest towns, and it was the general assembly at Lubeck which decided whether the whole Hanseatic confederacy was to take part in it. If the relief demanded consisted in troops, they were ordered to be in readiness to march before the expiration of fourteen days. In 1348 it conquered Eric 
and Hakon of Norway, and Waldemar III. of Denmark. After the peace of 1370, by which Denmark became a province of the League, no king could be elected without its approbation. It deposed Magnus, King of Sweden, and gave his kingdom to his nephew Albert, duke of Mecklenburg. In I428, Denmark becoming rebellious, it declared war against that kingdom, and invaded the country, sending thither 248 ships manned by 1 2,000 troops.-Exchange and Revieze, Philadelphia."

But these later dates have overlapped our English narrative, and I must pursue my chronological line.

I312. About this date the English Edward II. complained to the King of Norway of his suffering several English merchants to be imprisoned, and their goods seized to the value of $£ 310$ sterling, at the instigation of the Eastland merchants: who by all possible ways strove to obstruct the advantages of the English merchants.

I3 14. A grant entered in the Patent Rolls (sec. 7 Edw. II. m. I2) was made to the merchants of Germany, "mercatores Alemannia," of the coming securely into the kingdom and selling their merchandise; but in the following year direct mention is made of the merchants of the Hanse of Germany ; but three years later, when other privileges are granted, they are described as being to the merchants of the "Teutonic Gild."-Macpherson, p. 48.

\section{THE LEAGUE AND DENMARK.}

I348. A naval war began between the Hanse Towns and Waldemar III., King of Denmark, occas:oned by that monarch demanding toll for vessels passing the Sound. The circumstances of the contest are not clearly recorded; but that it terminated in favour of the League seems clear, from the circumstance that the king granted them the province of Schönen for thirteen years by way of a peace indemnity. This is the first known account of any toll demanded for passing the Sound : it has since been a bone of great contention.

Oddy says that soon after this date another war broke out between these same merchants, and the King of Denmark, 
"which ended much more gloriously for the former." This probably was the engagement which we speak of under date $136 \mathrm{I}$.

I36I. Wisby, the capital of Gothland, which had become one of the Hanse Towns in I24I (and was fortified in I289), was this year pillaged by Waldemar III. The League in consequence declared war against Denmark, forming an alliance with the King of Norway, Duke of Mecklenburg, and Earl of Holstein, which latter commanded the whole fleet, except the divisions belonging to Lubeck, for which that city named a commander itself. This federal fleet in 1362, attacked and took Copenhagen and its castle; but the Danish fleet overcame the Lubeck squadron, took six ships, burned others, and compelled the remainder to fly to the port of Travemunde. The defeat of the Lubeck squadron was soon repaired, and in 1364 the Hanseatic fleet totally destroyed the whole fleet of Denmark, in or near the haven or road of Wismar. Though the Danish King could not resist longer by sea, the Hanse Towns contrived to engage the King of Sweden in the quarrel; and Holstein and Jutland assisting the Danes, were compelled to make peace; and besides making new regulations for the toll payable in passing the Sound, great privileges were granted to the Hanse Towns throughout the Danish dominions.

\section{DOMAIN OF THE LEAGUE.}

I364. Some modern writers have been disposed to lay great stress upon this period in the history of the League. It is the date of the first meeting of the confederation held at Cologne, and certainly was the most important since that held at Lubeck in 1284 . It is further stated that the fundamental act of confederation was drawn up-a document since believed to be entirely lost to history. And it is also said that it was at this date that the general title of Hanse was adopted. The zenith of its splendour is believed to have been reached towards the close of this century, when there were eighty-six cities in confederation, viz.:- 


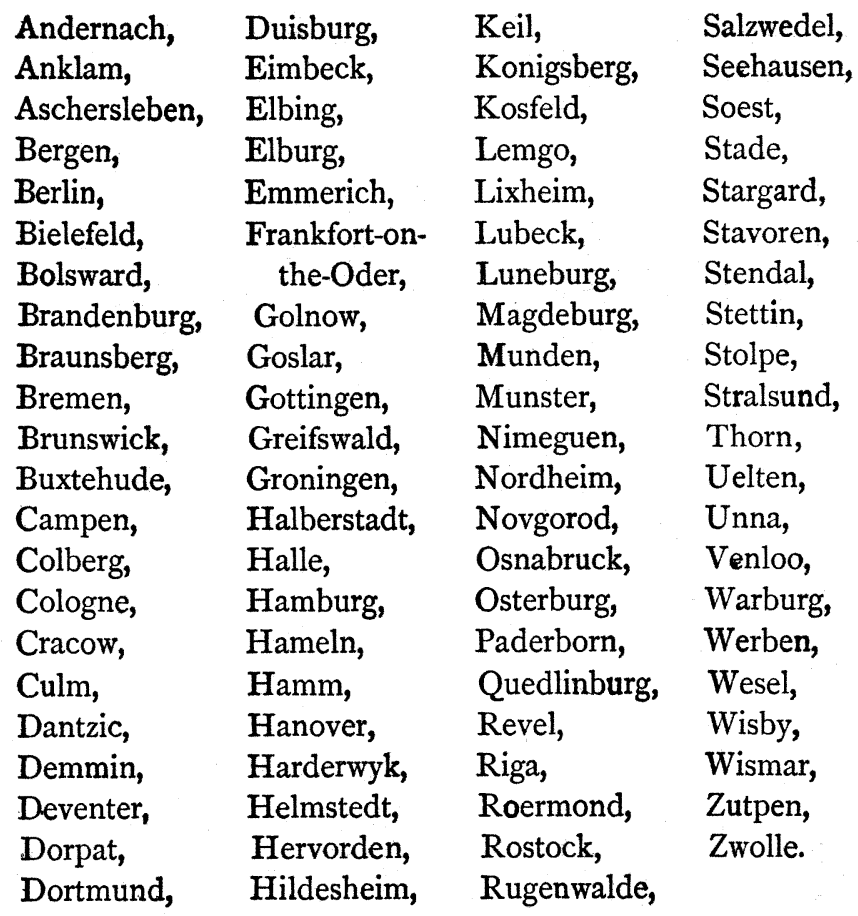

The following cities were also connected with the League, but did not have representation in the Diet, nor responsibility:-

$\begin{array}{llll}\text { Amsterdam, } & \text { Bordeaux, } & \text { Lisbon, } & \text { Ostend, } \\ \text { Antwerp, } & \text { Cadiz, } & \text { London, } & \text { Rotterdam, } \\ \text { Bayonne, } & \text { Dort, } & \text { Marseilles, } & \text { Rouen, } \\ \text { Bruges, } & \text { Dunkirk, } & \text { Messina, } & \text { Seville, } \\ \text { Barcelona, } & \text { Leghorn, } & \text { Naples, } & \text { St. Malo. }\end{array}$

Verdenhagen (vol. ii., chap. xxvi., p. 89) gives a list of sixtyfour towns, with the annual quota, ranging from 8 to Ioo imperial dollars, which each paid towards the usual current expenses, salaries, etc., amounting to about $£ 400$; also a list of 44 other towns and cities allied to the Hanseatic League, but some are doubtful.

The four great comptoirs or factories of the League, but which were not in confederation, were London, attached in 1250; Bruges, 1252; Novgorod (Russia), 1272; and Bergen 
(Norway), 1278. Acting chiefly from these centres, and negotiating advantageous treaties with the different nations of Europe, the League gathered into its confederated cities in course of two centuries of trading, the chief part of the wealth of Europe. The comptoir of Novgorod had many privileges, was regarded as a model, and was looked up to for support by all the towns in its region. This, I ought to state, is not the Nijni Novgorod, where the great fair is now held, but Novgorod on the Ilmen, in North-western Russia. Bergen was one of the most flourishing comptoirs, and the number of persons in its service was so considerable that a separate quarter consisting of twenty-one great buildings could hardly contain them. It had dependent upon it fortyeight chambers of Hanseatic merchants, having each its agents, clerks, \&c. Besides leather, skins, furs, butter, wood, train oil, whales and cod, and other fish from the northern countries and islands, this was the great depôt for salt, which was indispensable to the great herring fishery then carried on in the North Sea. The profits of the League upon salt were said to be enormous. It had an entire monopoly of the trade. The comptoir of Bruges maintained at one time three hundred merchants, factors, and journeymen, all told. After being employed herefor several successive years, they were appointed to the more eminent posts of the League, and were generally of such ability that directors and magistrates were selected from amongst them. This custom of promotion was long adhered to in all the comptoirs.

The League never had any commercial stations in Denmark or Sweden, hence the conflicts in which it was perpetually involved with those countries; in the ordinary way, however, it carried on very extensive trade with those kingdoms. The principal Baltic Staplehouse of the League was at Wisby, in the Isle of Gothland. This town became so famous for its riches that it was finally sacked and destroyed by Waldemar, King of Denmark, about 1361 .

1376. The magistrates and community of London petitioned the Parliament that they might enjoy their liberties, and that 
strangers might not be allowed to have houses, or to be brokers, or to sell goods by retail. Soon after, in the same Parliament, the community of the city represented to the King and Council that their franchises were invaded-merchant strangers acted as brokers, and sold goods by retail, and also discovered secrets to the enemy; and they prayed that a stop might be put to those enormities. Their petition was granted-"Saving to the German merchants of the Hanse, the franchises granted and confirmed to them by the King and his progenitors."-Cotton's Abridgment, p. I 33.

1383. Stow says these merchants of the Haunce had their Guildhall in Thames street, in place aforesaid by the said Cosin Lane. Their hall is large, built of stone, with three arched gates towards the street, the middlemost whereof is far bigger than the others, and is seldom opened. The other two be enured; the same is now called the old hall. At the date here given (6th Richard II.) they hired one house next adjoining to their old hall . . . this was also a great house with a large wharf on the Thames, and the way thereunto was called Windgoose, or Wildgoose Lane, which is now called Wildgoose Alley, for that the same alley is for the most part built on by the stilyard merchants.

1384. The Hanse Towns defeated those notorious pirates, known as the Vitaliens, who hailed from East and West Friesland, and who infested the Baltic, and interrupted the herring fishery. These pirates were afterwards used by the Hanse Towns in their conflict with Queen Margaret in 1395 (see that date).

Dr. Lujo Brentano, in the introduction to his "Essay on the History and Development of Gilds," printed by way of preliminary essay to Mr. Toulmin Smith's "English Gilds" (1870), says :

" But I strongly believe that the continual intercourse between the Towns of the several trading countries of the middle ages, kept up especially by the Hanse Towns, may not have been without influence in producing a general similarity of development of burgensic life in them all " (p. liv.) 
1392. The merchants of this Hanse obtained from the king a declaration that they should be subjected to no new impositions in any town. [Rd. pat., sec. I 5, Richard II. m. 36.]

About the close of this century the city of Brunswick incurred the sore displeasure of the League. The Trading Companies of the city rose in rebellion against the magistrates, putting some to death, and exiling others; and they induced other Towns also dependent upon the League to take a like course. The League came to the aid of the Dukes of Brunswick, and issued the most severe decree against the city, forbidding every communication between the inhabitants and the League, and depriving them of all the privileges theretofore enjoyed. Brunswick soon felt the effect of this ban. Commerce was destroyed, manufactories forsaken, the markets were empty, and a dreadful famine ensued. It was only upon the most abject repentance of the authorities, and the intercession of the Emperor Charles IV., that the Hanseatic Diet restored the privileges debarred for six years. Two burgomasters and eight of the principal citizens were condemned to walk in procession, bareheaded and barefooted, each with a lighted taper in his hand, from St. Mary's church to the Town-hall, where they were to confess their crime upon their knees before the Diet of Lubeck, and also to make sundry promises, and do other acts of penance.

1395. The League triumphed over Queen Margaret of Denmark-a woman of great ability and enterprise-who had united under her single authority, Denmark, Sweden, and Norway. They compelled her to deliver up King Albert and his son, who were her prisoners; and also to give them Stockholm. The cities of Lubeck, Hamburg, Dantzic, and five others of the League, bound themselves in the sum of 60,000 marks that King Albert should within three years resign the whole kingdom of Sweden. In this war England had granted three large warlike ships of Lynn, with their commanders and mariners, to enter into the service of the Queen.

Disputes with England.-It was about this period that 
England had various disputes and commercial differences with the League, through its then head, the Grand (or Great) Master of Prussia ; but they were all amicably settled. This affords an indication that England was now becoming a rising commercial power; and some of the towns of the League indicated jealousy thereat. There had come to be a notion among some of the Baltic towns that they were really masters of that sea ; and that, therefore, all who presumed to navigate the Baltic were invading their rights.

1399. King Henry IV. summoned the Grand Master of Prussia, and the Governors of Lubeck, Wismar, Rostock, Stralsund, and Gripwald, to appear in person or by deputies before his council to answer to the merchants of England, who complained that they were not treated in those places so well as the merchants from them were treated in England, though the express condition upon which they had obtained their privileges in England was that English merchants should enjoy the same advantages in their countries. He also warned the merchants of the Hanse, that if they allowed others to enjoy, under colour of their name, the privileges granted only to themselves, he would totally abolish and annul their charter. ("Fœdera," viii., p. I I2.) Macpherson, who quotes the preceding, adds by way of note: "When those conditions were stipulated the reciprocity was merely nominal, for there were very few Englishmen who traded to foreign countries ; but there were now many, and thence more frequent occasions of quarrel" (i. p. 6ro).

I 403. The Hanse Towns complained, in a General Assembly, but in very respectful terms, to Henry IV. (of England), that the Gascons (who were then subjects of England) had seized a ship belonging to Stettin; Lubeck complained in the same year of a similar injustice done on the coast of Great Britain. The League in these matters treated as a Sovereign with a Sovereign-being represented by its head, who at this date was designated the Master-General of the Teutonic Order of Prussia, thus reviving earlier associations than the League itself. 
I 409. In respect of damages awarded out of some of the complaints already noted, Henry IV. this year gave his obligation to the Master-General for 5,318 $\frac{1}{2}$ golden nobles, and I $3 \mathrm{~d}$. to be paid next St. Martin's Day, on the express condition that when the money should be paid to the envoy of the Master-General in England it should be sent out of the country by bills of exchange, and not in bullion or coin, except so much as was necessary for expenses.

I4I I. The same English monarch arrested several Hanseatic merchants in the port of Boston, until satisfaction should be made for divers losses and murders committed by them on English merchants trading to Bergen. On giving security to the amount of 2,000 marks, they were however released the following year.

1417. At this date the Herring Fishery appears to have deserted the North Sea, and to have become established in Flanders. This was apparently one of the first steps which operated towards the decadence of the League. The Dutch were now rapidly increasing in wealth and rising in maritime importance; and this event had considerable influence on the fortunes of the confederation. (See I43I.)

1428. The Hanse Towns of the Baltic fitted out, at the Port of Wismar, a fleet of 260 ships, carrying 12,000 , which were intended a second time to destroy Copenhagen; but notwithstanding their numbers and force they did not succeed. After this Erickson X., King of Denmark, contrived by intrigue to render the people in some of the Hanse Towns jealous of their magistrates, by which he gained over some of them.

I426. Formerly one of the aldermen of London used to act as judge in mercantile causes, wherein the German merchants of the Hanse residing in England were parties; but for above seven years the magistrates of London had refused to appoint any one of their number to sit in that capacity. After repeated applications of the Hanse merchants to Parlia. ment, the King now nominated Crowmer to the office of alderman and judge of the Hanse merchants. 
We have already seen [1282] that an alderman of London was designated "Alderman of the Haunce." His office was that last indicated.

\section{BEGINNING OF TROUBLES.}

143I. The League was again at war with the King of Denmark, and were in the end obliged to sue for that peace they had so long refused. Ships of foreign nations seized the opportunity, while the Towns which had maintained certain special trades were engaged in war, of passing through the Sound and obtaining trading advantages for themselves.

1432. The Commons in Parliament proposed (or petitioned) that the Hanse merchants settled in London should be made liable for compensation to those whose property should be seized by the Hanse merchants in their own countries. But the King could not consent.-Cotton's "Abridgment," p. 604 .

1436. Early in this year the English merchants were so much offended at being prohibited from sailing to Iceland that they got a petition presented to Parliament praying the abolition of the privileges of the Easterlings (or Hanse merchants) in England. But the King would not agree to it.

A few months later the commissioners of King Henry VI. settled a treaty with those of the Grand Master of Prussia, the cities of Lubeck and Hamburg, and the Hanse Towns, whereby the ancient privileges were confirmed on both sides. The merchants of Prussia and the Hanse Towns were exempted from the jurisdiction of the Admiral of England; and were indulged with an option of having any causes, wherein they should be concerned, tried with despatch, and without the bustle and formality of a law suit, by two or more judges to be appointed by the king : and a similar mode of trial was stipulated for the causes of English merchants in their countries. It was further stipulated on both sides, that in case of any depredation at sea, the inhabitants of the port, from which the piratical vessel sailed, should be obliged to make compensation, agreeably to an order of King Edward, 
and that sufficient security to that effect should be given before any armed vessel should go out of port.-“ Fœdera," vol. x., p. 666.

I437. England, through her monarch Henry VI., showed a sudden disposition, either through fear or interest, to cultivate amicable relations with the League. $\mathrm{He}$ granted to the Hanse Towns all the privileges they had formerly enjoyed in England, in the fullest manner, and also agreed to pay $19,274 \frac{1}{2}$ nobles to the Grand Master, in annual sums of $I, 000$. This appears to us to have been, not unlikely, in view of suppressing the growing commercial power of Holland.

I440. King Henry VI. addressed an expostulatory letter to the Grand Master of Prussia, stating that in former times no duties were exacted for vessels or cargoes in Prussia, but of late the merchants of England had often been compelled to pay a duty upon the value of their vessels and cargoes in Dantzic, and been oppressed with other arbitrary exactions, detention of their vessels, \&c. Some English merchants also having complained of being wrongfully imprisoned and plundered in the towns of Stettin and Cosselyn, the King wrote also to the Burgomasters, Proconsuls, \&c., of the Hanse Towns, demanding redress. ("Fœdera," x., pp. 753-5.)

1447. We have seen it stated that an English statute made this year ( 26 Henry VI.) prohibited the exportation of merchandise in any other vessels than those belonging to the League, but we cannot find any such. It may have been simply a proclamation. As a matter of fact no statutes were enacted this year.

1448. Disputes had again arisen between England and the League, and Cornmissioners were appointed to meet those of the Grand Master of Prussia and settle all differences.

1452. In a Diet which had been held at Utrecht by the Commissioners [those appointed in 1448 , we presume] the matters in dispute were adjusted in a manner satisfactory to the King and the Grand Master. But the citizens of Lubeck refused to abide by the determination of the Diet, retained a number of English subjects in prison, and even prescribed to 
the King rules for the conduct of his subjects. The other Hanse Towns appear, in complaisance to Lubeck, to have also neglected to accept or ratify the acts of the Diet. The magistrates of Cologne, however, apprehending the displeasure of the English Sovereign, had written to him requesting the continuance of his favour, and the merchants of the Teutonic Guildhall in London importuned him to the same effect. The King now wrote, in answer to the magistrates, that nothing should be wanting on his side to the faithful preservation of the ancient friendship between England and Cologne ; and he desired to know whether the Hanse Towns were to take part with Lubeck in the hostile conduct of that city towards England, or to comply with the decrees of the Diet. $\mathrm{He}$ also wrote in the same manner to the Grand Master, in answer to his letter, signifying his approbation of the proceedings of the Diet.- "Fodera," xi., pp. 304-5.

1454. The Grand Master of the Teutonic Order, by laying heavy taxes upon new towns in the north of Germany, gave rise to much dissatisfaction, and remonstrance not availing, the inhabitants joined with the nobles in a league of self-defence. The Emperor Frederick III. took the Grand Master under his protection, while the opposition had recourse to Casimir, King of Poland, for assistance. The war lasted twelve years, and Poland, in 1466, got possession of the country afterwards known as Polish Prussia, with the city of Culm. The Teutonic knights became so reduced that they had to submit to hold the remainder of their territory as a fief of the crown of Poland. This was a great blow to the League.

1463. King Edward IV. gave the merchants of the Teutonic Guildhall in London a confirmation of all the privileges granted by his predecessors ; and he also exempted them from all new taxes imposed, or to be imposed, on imports or exports. These privileges they were to enjoy during two years and a half, to be computed from Christmas, 1462, provided they should not attempt to pass the goods of others as their own, nor commit hostilities or depredations against himself or his subjects. 
But notwithstanding this the Parliament which sat this year for the defence of the realm, and especially for the guard of the sea, granted the king for life a subsidy, called tonnage, of 3 s. upon every tun of wine imported, and 3 s. more upon every tun of sweet wine imported by any foreign merchants, those of the Hanse not excepted. They also granted a poundage duty of $\mathrm{I} 2 \mathrm{~d}$. on the prime cost value of all goods exported or imported, to be paid by natives as well as merchants of the Hanse, and other strangers, who should, however, pay double poundage on tin. From this duty were excepted woollen cloths made by English-born subjects, wool, wool-fells, hides, and provisions for Calais exported ; also the flour of all kinds of corn, fresh fish, animals, and wine imported. These impositions are said to have been made under the authority of 3 Edward IV., but no such act appears in the Statute Book. There is just a supposition of intended distinction between the merchants of the Teutonic Guildhall and those of the Hanse League; but it is not very probable.

One of the first acts of protective legislation in the matter of food in this country was this year directed against the customs of the "Easterlings" (as declared established by them in 1252), viz., the 3 Edward IV., c. 2, under which grain ("corn") was forfeited if imported when the price of wheat here was under $6 \mathrm{~s}$. $8 \mathrm{~d}$. the quarter, rye $4 \mathrm{~s}$. and barley $3 \mathrm{~s}$. This act was continued in force for a very considerable period. The other articles of commerce imported by the Easterlings at this date were cordage, linen, cloth, hemp, flax, pitch, tar, masts, pipe-staves, steel, iron, wax, and wainscot.

I 469. The Grand Duke of Muscovy began to makeconquests, and amongst others obtained the commercial city of Novgorod, which he pillaged and destroyed. The Hanse Towns then removed their emporium to Revel, where it remained about half a century, from whence it was removed to Narva.

\section{TREATY WITH ENGLAND.}

I 475. The citizens of Lubeck, who had latterly distinguished themselves beyond their confederates by a spirit of hostility 
to England, had, in April, 1473, sent deputies to a general assembly of the representatives of the Hanse Towns held at Bruges, with instructions to ratify the articles agreed upon with King Edward's commissioners [in 1452, or subsequently]! After several adjournments three commissioners from the King, with the representatives of Lubeck, and two or three from each of the cities of Bremen, Hamburg, Dortmund, Munster, Dantzic, Daventer, Campen, and Bruges, the Society of the Merchants' Hanse in London, and the Society of those in Bergen, met at Utrecht, in order to settle the terms of a permanent amicable intercourse, and now concluded a treaty in substance as follows :-

"Heads of Treaty.-All hostilities should cease, and a free intercourse by land and water should be restored. All suits for compensation on either side should be dropped, and all injuries be buried in oblivion. No claims should be made upon vessels or other property by those from whom they had been taken, nor the captains of ships or others be liable to arrest for any past quarrels. This general amnesty should be confirmed by the King and Parliament of England, and all obligations entered into by the Hanse merchants in England for compensation of damages should be cancelled. The merchants of England might trade to Prussia and other places of the Hanse freely as in former times, and should be charged with no customs or exactions but what had been a hundred years established, and the merchants of the Hanse should enjoy all the privileges in England granted by any of the kings to their predecessors. The King and Parliament of England and the Hanse Confederacy, by Letters under the seal of the city of Lubeck, should certify that no pretence of forfeiture of privileges on account of the late hostilities should be advanced on either side. In civil or criminal causes wherein the Hanse merchants might be concerned in England the King should appoint two or more judges, who, without the formalities of law, should do speedy justice between the parties, the merchants and mariners of the Hanse being entirely exempted from the jurisdiction of the Admiralty and other Courts ; and similar provision should be made for the easy and speedy dispensation of justice in the Hanse countries. As part of the recompense found due by the English to the Hansards, the King should convey to them the absolute property of the courtyard, called the Staelhoef or Steelyard, 
with the buildings adhering to it extending to the Teutonic Guildhall in London, and also a court-yard, called the Staelhof or Steelyard, in Boston, and a proper house for their accommodation near the water in Lynne, they becoming bound to bear all the burdens for pious purposes to which the Staelhoef was made liable by ancient foundation, or the bequests of the faithful, and having full power to pull down and rebuild as they might find convenient. After discussing the claims for pillages of ships and cargoes and other outrages committed on both sides, the sum of $\mathcal{E}^{\mathrm{I} 5}, 000$ sterling was found due as a balance of compensation from the English to the Hansards, besides the above-mentioned houses; but in consideration of the protection against suits for by-past grievances assured to them by the King, they agreed to reduce the sum to $£$ Io,०oo, and to receive the payment in the customs falling due on their subsequent imports and exports. If any city should be dismembered from the Association of the Hanse, the King, upon receiving due intimation, should put the merchants of that city upon a footing with other foreigners till he should be duly certified that they were re-admitted into the Association. The City of London should be bound by the present Treaty in transactions with the Hanse merchants, whose ancient privileges should not be impaired by any later grants made to the city, and the Hanse merchants should still have the keeping of Bishopsgate as formerly. The King should oblige the public weighers and measurers to do justice between the buyers and sellers, and he should prevent vexatious delays at the Custom House, and the repeated opening of the packages containing federatures and other precious furs and merchandise [after being sealed as having paid the customs] at Canterbury, Rochester, Gravesend, and elsewhere, and should abolish the exaction of prince-money and some other unlawful charges. Wrecked vessels should be preserved for their owners on the usual conditions. The King should make diligent provision against defects in the length or breadth of cloths, in the quality of the wool. The merchants of the Hanse, after giving security to abide the law in such cases, as their property used to be arrested for, should have perfect liberty of selling their goods as they pleased, and of retailing Rhenish wine, according to ancient usage; neither should the Mayor of London claim a portion of their salt as he used to do."

I have set out the heads of this treaty thus in detail as indicating very distinctly what had been the previously 
existing grievances, and feel bound to add that the great majority of the offences appear to have been committed by the English.

I476. Under date 1452 we have seen the citizens of Cologne in friendship with England, when all the members of the Hanse Association were hostile, or at least unfriendly: and the former alone enjoyed the privileges of the Hanse in England: though for very short terms, and subject to the trouble and expense of frequent renewals. In consequence of that distinction Cologne had either withdrawn itself or been expelled from the confederacy. But now that all the Hanse Towns were in friendship with England, Cologne was again received into the association; and, agreeably to the treaty of the preceding year, due notice was sent to King Edward by the magistrates of Lubeck, in the name of the whole Teutonic Hanse. ("Fœdera," xii. p. 36.)

\section{DOMINION OF THE LEAGUE AT THIS DATE.}

The geographical constitution of the League, at this date, appears to have consisted of the following divisions-the Towns varying from those given in 1364 in some details. LUBECK, chief city of the first region; other cities attached thereto:

$\begin{array}{lll}\text { Hamburg } & \text { Lunenberg } & \text { Gripswald } \\ \text { Rostock } & \text { Stettin } & \text { Colberg } \\ \text { Wismar } & \text { Anclam } & \text { Stargard } \\ \text { Stralsund } & \text { Golnow } & \text { Stolpe }\end{array}$

CoLOGNE, chief city of the second region, in which were comprehended :

$\begin{array}{lll}\text { Wesel } & \text { Hervorden } & \text { Venlo } \\ \text { Duesberg } & \text { Paderborn } & \text { Elburg } \\ \text { Emmerich } & \text { Lemgon } & \text { Harderwick } \\ \text { Warburg } & \text { Bilefeld } & \text { Daventer } \\ \text { Unna } & \text { Lipstadt } & \text { Campen } \\ \text { Ham } & \text { Coesfeld } & \text { Swolle } \\ \text { Munster } & \text { Nimeguen } & \text { Groningen } \\ \text { Osnaburg } & \text { Zutphen } & \text { Bolswert } \\ \text { Dortmund } & \text { Ruremond } & \text { Stavern } \\ \text { Soest (Zoist ?) } & \text { Arnheim } & \end{array}$


OUTLINE HISTORY OF THE HANSEATIC LEAGUE. 111

BRUNSWICK, the capital of the third region, had under its command :

$\begin{array}{lll}\text { Magdeburg } & \text { Hildesheim } & \text { Stade } \\ \text { Goslar } & \text { Hanover } & \text { Bremen } \\ \text { Einbeck } & \text { Ulsa } & \text { Hamelen } \\ \text { Gottengen } & \text { Buxtehude } & \text { Minden }\end{array}$

DANTzIC, the chief city of Prussia, was at the head of the fourth region, consisting of :

$\begin{array}{ll}\text { Koningsberg } & \text { Brunsberg } \\ \text { Colmar } & \text { Riga } \\ \text { Thorn } & \text { Dorpt } \\ \text { Elbing } & \text { Reval }\end{array} \quad\left\{\begin{array}{l}\text { and also } \\ \text { sundry } \\ \text { Towns in } \\ \text { Slavonia }\end{array}\right.$

There was also another class of cities whose right to the privileges of the League were controverted, viz. :-

$\begin{array}{lll}\text { Stendale } & \text { Breslau } & \text { Halberstadt } \\ \text { Stoltwedale } & \text { Cracow } & \text { Helmstadt } \\ \text { Berlin } & \text { Halle } & \text { Ryla } \\ \text { Brandenburg } & \text { Sschersleben } & \text { Nordheim } \\ \text { Frankfort-on-the- } & \text { Quedlinburg } & \text { Dinant } \\ \quad \text { Oder } & & \end{array}$

Werdenhagen extends the number of cities of this last class to forty-four, among which were Lisbon and Stockholm.

The four chief "Factories" of the Hanse were Novgorod, London, Bruges, and Bergen; but the London Factory had branches, or depôts, at Lynn and Boston, then important maritime towns. All the merchants of every one of the Hanse Towns had a right to trade to those factories and enjoy all the privileges obtained from the Sovereigns of the countries conforming to the regulations enacted for the general good of the whole confederacy.

I49I. Notwithstanding the treaty so formally concluded with the Hanse Confederacy in 1475, the jealousies and collisions which became more frequent as the English came more and more into the situation of rivals in trade, had again broken out in hostilities, captures, and slaughters. A meeting of deputies from both sides was now held in Antwerp, in 


\section{TRANSACTIONS OF THE ROYAL HISTORICAL SOCIETY.}

order to adjust the pretensions and compensate damages. But the assembly broke up without coming to any accommodation (vide Werdenhagen II., part iv., c. IO).

1493. Henry VII. of England broke off commercial relations with the Netherlands, and banished the Flemings out of England: whereupon the Archduke Philip banished the English out of Flanders, which carried all the English trade directly to Calais. This rupture was of serious consequence to both countries. It gave the merchants of the Steelyard a very great advantage, by their importing from their own Hanse Towns great quantities of Flemish merchandise into England, to the considerable detriment of the Company of English Merchant Adventurers, who were wont to import such directly from the Netherlands; whereupon the London journeymen, apprentices and mob attacked and razed their warehouses in the Steelyard; but those rioters were soon suppressed and duly punished (vide Macpherson, ii., p. 6).

I 502. There were differences between the Hanse Towns and the King of Denmark; who having been driven out of Sweden by the Regent, insisted that the Hanse Towns should forbear trading to Sweden. The Hanse merchants contended that it was their business to push commerce wherever they could. The King was assisted by the Ambassador of his uncle James IV., King of Scotland, who sent an aid of two stout ships of war. At a General Assembly the merchants convinced the $\mathrm{King}$ of the unreasonable nature of the demand, as the League had great business ventures in Sweden.

I503. There was enacted, I9th Henry VII., c. 23, "For the merchants of the Hanse :"

" Be it ordained, established, enacted, and provided by the King, our Sovereign Lord; by the advice of the Lords Spiritual and Temporal, and the Commons of the same, in the present Parliament assembled, for merchants of the Hansea of Almain, having the Hanse in the City of London, commonly called Guildhallda Teutonicorum. That by the authority of this said Parliament every Act, Statute, or Ordinance, Acts, Statutes, or Ordinances, heretofore made concerning Merchants, Merchandise, or other wares, extend not to 
the Prejudice, Hurt or Charge of the said Merchants of the Hanse contrary to their ancient Liberties, Privileges, free Usages, and Customs of Old Time granted to the said Merchants of the Hanse, as well by the King's noble Progenitors, and ratified and confirmed by the King's Grace, or by Authority of divers Parlia . ments (2) but that all such Act, Statute and Ordinance, Acts, Statutes, and Ordinances made or to be made in derogation of their said Liberties, Privileges, and Free Usages and Customs stand to be, as against the said merchants and their successors, and every one of them, void, repealed, and annulled and of none effect; any Act, Statute, or Ordinance, Acts, Statutes, or Ordinances to the contrary made or to be made notwithstanding. (3) Provided alway, That this Act or anything therein contained, extend not, nor be in any wise prejudicial or hurtful to the Mayor, Sheriffs, Citizens, or Commonalty of the City of London, or any of them, or the successors or any of them, or of any Entries, Liberties, Privileges, Franchises, or other Thing to them or any of them given, or granted by the King's most noble Progenitors or Predecessors, Kings of this Realm, or by authority of Parliament, or otherwise ; this present Act or any Thing therein contained notwithstanding."

This and a similar one passed in 1523 are the only Acts which we find in the English Statute Book relating to this fraternity.

I 505. A conflict now arose-it had been smouldering for some time-between the English Company of Merchant Adventurers and the League. The Easterlings had been entering upon the trade of woollen cloths with the Netherlands. King Henry VII. had reserved this branch of trade to the first-named company, and he not only strictly prohibited the merchants of the Steelyard from entering, or rather from continuing it, but he obliged the Aldermen of the Steelyard to enter a recognisance of 2,000 merks that the Steelyard merchants should not carry any English cloth to the place of residence of the Merchant Adventurers in the Low Countries. This remedy was only effective for a short time.

I 5 IO. Ships from all parts of Europe were now trading in the Baltic; and the city of Lubeck having imprudently attacked the King of Denmark, and burned several places on the coast, that monarch pressed into his service the ships 
of England, Scotland, and France. Sweden joined the Hanseatics ; and Denmark hired at a high charge further aid by ships from the three countries that had espoused her cause, and thereby obtained a larger fleet than her opponents. The port of Lubeck, with all the ships in it, was burned; as was likewise that of Wismar, together with the suburbs of the town. Warnemunde was destroyed, and the suburbs of Travemunde, together with many villages belonging to Stralsund and Rostock.

These events constituted another serious blow to the League; and others were soon to follow. It appears from De Witt's "True Interest of Holland," that that nation aided Denmark in this warfare-eight of her ships having been previously taken by the Lubeckers-and that this war cost the province of Holland no less than fifty ships. The circumstances are set forth in considerable detail in Macpherson's "Annals of Commerce" (ii., p. 38).

The rapid rise in commercial importance of Copenhagen was regarded as another blow to the League, although it was really brought about very much by the policy of the League itself. The Hanse Towns had long oppressed the Danish merchants who came into their ports with goods: they fixed an arbitrary price on their merchandise, and refused to the Danes the right of carrying away what they could not sell to advantage. The only remedy, therefore, was to warehouse their goods with some person in the town till circumstances might become more favourable. To revenge as well as remedy this, it was ordered by the King of Denmark that all such merchandise should in future be exposed for sale only at Copenhagen, to which place he invited foreign merchants; so that it became an emporium for all Danish merchandise, to the great detriment of all the Hanse towns in the Baltic.Oddy, p. 24.

I5 16. This year terminated a six years' war between Denmark and the merchants of Lubeck, which affected the commerce of one section of the Hanse Towns seriously; for during this period the city of Hamburg carried on all the 
trade with Denmark and Norway, to the exclusion of Lubeck and the other Vandalic cities which had joined her. Here, then, we see divided interests cropping up in the several sections of which the League was composed. Hamburg's trade with the Netherlands, and with England, vastly increased during this period.

I5I8. At this date fourteen of the Hanse Towns were cut off from the League or general confederacy; which they were, or what was the precise cause, we are not informed. We do, however, know that the League still consisted of sixty-six cities in confederation, viz., six Vandalic cities, eight of Pomerania, six of Prussia, three of Livonia, thirteen Saxon cities, ten of Westphalia, seven of Cleves or Marck, three of Overyssel, seven of Guelderland, and three of Friesland. This number, with the fourteen which had been cut off, make a total of eighty. Over a period of many centuries, with new political and mercantile combinations, there must almost necessarily have been many changes.

Another significant fact which transpired at this period was that in the Commercial Treaties which England had made with other Powers, and with France especially, had been generally comprehended the community and society of the "Teutonic Hanse," and this had been so to a greater or less extent for a century past. In a treaty made this year with France against piracy this association was expressly comprehended. This could not in any way mean the Hanseatic League?

I5 I9. King Henry VIII. of England issued a commission for a congress at Bruges to treat with Commissioners from the Hanse Towns, concerning the abuses, unjust uses, extensions, enlargements, interpretations and restrictions made by the Hanseatic merchants, concerning the several privileges at any time granted to the Hanseatic League -by the King or his predecessors, and to remove all the said abuses ; also to demand and receive whatever sums of money, and how large soever they may be due to him on that account. And finally to renew and conclude an intercourse of commerce between 
England and the said Hanse League. The issue of this Congress does not appear; and it is more than probable that nothing was done.

1522. Weare told by Oddy ("European Commerce") that the League was about this date so much engaged in quarrels with various powers that the danger of membership became nearly a counterpoise to the protection it afforded. On the other hand the League received considerable advantage from a quarrel which broke out between Denmark and Sweden, when Lubeck and Dantzic lent to Gustavus Vasa nine ships of war, which turned the fortune of the day; so that the Hanse Towns received in recompense great privileges from the Swedish monarch, as being allowed the sole trade of Sweden, and to pay no custom there for merchandise imported, \&c.

I 525. So rapidly does the kaleidoscope of history change that we find recorded by Macpherson the occurrence of three important incidents this year:

I. The Hanse Towns were still so powerful that Frederick I., King of Denmark, was induced to desire a union with them, being herein seconded by the Great Master of Prussia.

2. Even the Lubeckers alone fancied themselves so far masters of the northern kingdoms, that they had already sold Denmark to Henry VIII., King of England, who had actually advanced to them 20,000 crowns on this account ; but wisely put off payment of the remainder till they should fulfil their engagement. [This upon the authority of Puffendorf's "History of Sweden."]

3. King Gustavus Erickson, of Sweden, about this time agreed with Frederick I., of Denmark, to refer their differences about the Island of Gothland and the Province of Blekinga, \&c., to the six following Hanse Towns, viz., Lubeck, Hamburg, Dantzic, Rostock, Wismar, and Lunenburg ; between which towns and those two kings an alliance was made against the expelled King Christian II., who claimed all the northern crowns; by which alliance a final period was put to the union of these three kingdoms, which the Swedes alleged had ever been prejudicial to them, but beneficial to 
the Danes, who, whilst they commanded in Sweden, lived like opulent lords, whereas the native Swedes were slaves and beggars. ("Annals of Commerce," ii., p. 64.)

1535. England again favoured the League with her coun. tenance, although it was only in the way of retaining its services. Relying on its former renown, probably, Henry VIII. offered 100,000 crowns for the aid of the League in placing a king of his liking on the throne of Denmark. The merchants undertook this political speculation; but Gustavus of Sweden, to whom the Towns had been insolent since the time they had assisted him, joined the Danes ; the Hanseatics were defeated in an engagement at sea, and lost a vast number of their ships, thereby hastening the decline of the League.

\section{DECLINE OF PRIVILEGES AND POWER.}

I552. We now arrive at another important stage in the history of the League. To make events clear we had better fall back upon the summary given by Macpherson at this juncture:

"The time was now at length come when the eyes of the English were to be opened to discern the immense damage sustained by suffering the German merchants of the Hanse or College in London, called the Steelyard, so long to enjoy advantages in the Duty or Custom of exported English cloths, far beyond what the native English enjoyed, which superior advantage enjoyed by those foreigners began about this time to be more evidently seen and felt, as the foreign commerce of England became more diffused.

"The Cities of Antwerp and Hamburg possessed at this time the principal commerce of the northern and middle parts of Europe; and their factors of the Steelyard usually set what prices they pleased both on their imports and exports; and having the command of all the markets in England, with joint or united stocks they broke all other merchants. Upon these considerations, the English Company of Merchants. Adventurers made pressing remonstrances to the Privy Council. These Hanseatics were moreover accused (and particularly the Dantzicers) of defrauding the Customs by colouring (i.e., taking under their own names, as they paid little or no Custom) great quantities of the merchandise of other Foreigners not entitled to 


\section{TRANSACTIONS OF THE ROYAL HISTORICAL SOCIETY.}

their immunities. They were also accused of having frequently exceeded the bounds of even the great privileges granted to them; yet by the force of great presents, they had purchased new grants. They traded in a body, and thereby undersold and ruined others. And having for the last 45 years had the sole command of our commerce, they had reduced the price of English wool to Is. $6 d$. per stone. - . . In the preceding year they had exported no fewer than 44,000 woollen cloths of all sorts, whilst all the English merchants together had in the same exported but $\mathrm{r}, \mathrm{r}$ oo cloths. The Steelyard merchants were also exempted from aliens' duties, and yet all their exports and imports were made in foreign bottoms ;-a very considerable loss to the nation."

Upon mature consideration of these, and such like reasons and arguments, as well as of the answer thereto by the Steelyard or Hanseatic Merchants ; and of Records, Charters, Treaties, Depositions of Witnesses, and other proofs, it was made apparent to the King's [Edward VI.] Privy Council :

I. That all the liberties and privileges claimed by, or pretended to be granted to the merchants of the Hanse, are void by the laws of this Realm, forasmuch as they have no sufficient corporation to receive the same.

2. That such grants and privileges claimed by them do not extend to any persons or Towns certain, and therefore it is uncertain what persons or what Towns should or ought to enjoy the said privileges, by reason of which uncertainty they admit to their freedom and immunities as many as they list to the great prejudice of the King's customs and the common hurt of the Realm.

3. That supposing the pretended grants were good in law, as indeed they were not, yet the same were made on condition that they should not colour any other foreigners' merchandize, as by sufficient proofs it appears they have done.

4. That above one hundred years after the pretended privileges granted to them they used to transport no merchandise out of this realm, but only to their own countries ; neither did they import any merchandise but from their own countries: whereas at present they not only convey English merchandise 
into the Netherlands, and there sell them to the great damage of the King's own subjects, but they all import merchandise of all foreign countries, contrary to the true intent and meaning of their privileges.

5. That in the time of King Edward IV. they had forfeited their pretended privileges by means of war between the realm and them (i.e. the Hanse Towns), whereupon treaty was made [see I475] stipulating that our English subjects should enjoy the like privileges in Prussia, and other Hanseatic ports, and that no new exactions should be laid upon their persons or goods. Which treaty has been much broken in several parts, and especially at Dantzic, where no redress could ever ba obtained either by the requests of the King's father or himself, for the said wrongs.

In consideration of all which, the council decreed that the privileges, liberties and franchises claimed by the said merchants of the Steelyard shall from henceforth be and remain seised and resumed into the King's grace's hands until the said merchants of the Steelyard shall declare and prove better and more sufficient matter for their claim in the premises; saving, however, to the said merchants all such liberty of coming into this realm and trafficking, in as ample manner as any other merchant strangers have within the same.

It appears that this decision was immediately followed by the imposition of a heavy duty upon the merchandise imported and exported by the League-20 per cent. instead of I per cent., their ancient duty since Henry III. We find no trace of it ; but it may have been effected by proclamation. It is certain that the Regent of Flanders, as also the City of Hamburg, made representations in view of having the privileges of the Steelyard merchants reinstated, but without effect.

1553. Misfortunes rarely come singly, and so we must be prepared to find that events were transpiring in other directions similar to those last recorded-the incidents of diplomacy frequently react upon each other, and it may have been so in this case. We learn from Wardenhagen that there was at this date trouble at two other comptoirs of the League 10 
-viz., at Novgorod, which "by reason of the Czar's arbitrary and tyrannical proceedings (who without any just grounds, assumed a power to imprison the German merchants, and to seize on their effects) was now quite abandoned ;" and at Bergen-where the marks of the once important commerce of the League are more clearly seen than elsewhere-which had also become deserted by the Hanseatics by reason of the like arbitrary proceedings of the King of Denmark. The remaining comptoir had originally been at Bruges, but by reason of the decay of that once most opulent city, it had been first removed to Dort, and afterwards to Antwerp, where it continued to prosper for a considerable time hereafter.

There can be no doubt that the real decline of the power of the League is to be traced to the fact of its having become political and warlike instead of remaining commercial and peaceful ; for if the latter policy had been pursued it might, and probably would, have rivalled and distanced all other trading enterprises of early date. Mr. Oddy's summing up on this point is instructive:

The Hanseatic Towns had, in those days, when they understood the nature and importance of commerce better than other nations, obtained from their merchants privileges that in times when those latter grew more enlightened, became burdensome and obnoxious ; but the members of the League, by a fatality (if it may be so called), or at least by a conduct which is very common to nations and States in the time of prosperity, never took into account the changes that time and circumstances had brought about; they never considered that the time was past when they could either deceive, cajole, or coerce other l owers, and that therefore they must depend on prudent management for the preservation of those advantages they had obtained under more favourable circumstances.

The sort of treatment political resentment brought upon the League is very well shown in the following case. The ancient toll for passing the Sound had only been a golden rose-noble on every sail, which was always understood to be meant on every ship [the only reasonable construction]; but 
the Court of Denmark had for some time past put a new and arbitrary construction on the word sail, by obliging all ships to pay a rose-noble for every sail in or belonging to each ship. Moreover, not content with this imposition, the same Government proceeded to lay a duty on the grain and other merchandise per last or ton, distinct from that on sails; which burdens obliged the Vandalic Hanse Towns to relinquish the Norway trade. And as they had vast dealings in transporting the grain of Poland and Livonia to other parts of Europe, these high tolls so discouraged them that they gradually left off that commerce, to which the Hollanders succeeded, and conducted with great advantage. As we have said, this is but one instance of a class.

1554. The English Mary having in the previous year married Philip, son of the Emperor, the prospects of the Hanseatics began, at least for the moment, to revive in England. Her first act in their behalf was to suspend the operation of the regulations imposing the higher duty upon their imports and exports for a period of three years. This led the ambassadors of the Free Cities of the League to point out that, by an act of the first year of her reign (1 553) imposing certain customs or subsidies, called Tonnage and Poundage, they were more burdened than heretofore, " contrary to the effect of such charters and privileges as by sundry of her predecessors, Kings of England, had heretofore been granted to them." And the Queen being informed that the said declaration or complaint contained truth, and she being also desirous to observe and continue in equitable and reasonable sort the antient amity and intercourse which had been betwixt her dominions and the free cities of the Hanse Towns, commanded her Treasurers and Barons of the Exchequer, her Customers, Comptrollers, Searchers, \&c., in London and other ports, freely to permit the said merchants of the Steelyard to import and export all merchandise not prohibited, without requiring any greater subsidy or custom than in the time of her father or brother. She also granted them a licence to export woollen cloths made in England, of the value of $£ 6$ 
sterling, or under, unrowed, unbarbed, and unshorn, without any penalty or forfeiture on account of certain Statutes of the 27th and 33rd years of King Henry VIII., prohibiting the said exportation; the merchants of the Steelyard representing to the Queen that the price of cloths was now so enhanced that they could send over none at all without incurring the penalties of those Acts.

The last portion of this record is not by any means so clear as it might be, but we have preferred to follow our authority ("Fodera," xv., p. 364). The most remarkable portion, however, of the history in this reign remains yet to be told. The Queen afterwards revoked the said privileges, for that the Hanses had broken promises with her, in continuing an unlawful trade in the Low Countries, whereby she lost in eleven months, in her customs, more than $£ 9,660$, besides great damage to her subjects in their trade.-Vide Wheeler's "Treaties of Commerce," p. Ioo.

I 558. Queen Elizabeth ascended the English throne. She and her advisers speedily found themselves involved in misunderstandings with the League; and it seems quite probable, from the recent course of events, that some so-called religious feeling was becoming introduced into the constantly recurring disputes. We shall, however, confine ourselves entirely to the commercial and political aspects, under their appropriate dates (see 1568 and 1578 ).

1568 . We obtain in the following passage from Macpherson a more clear view of the causes of the disputes in this reign with the League than we have elsewhere seen :

"As England produced no military stores, Queen Elizabeth was obliged to buy all her gunpowder and naval stores from the German Steelyard merchants, at their own prices, there being as yet but few English merchants dealing in that way, and this was one of her greatest inducements to encourage commercial companies, whereby her own Merchants of Russia, and of the two Elder Companies of the Staple, and the Merchant Adventurers, were considerably increasing in trade-the former in the exportation of wool (not as yet legally prohibited); and the latter, of cloth, both to the great 
advantage of the revenue. This made the Hanseatics labour to render these companies obnoxious to other nations by various calumnies ; yet, in spite of their malice, an universal spirit of adventuring in foreign parts for discovery and trafflc, as well as for improving manufactures at home, daily increased in England, whereby they soon became an overmatch in naval strength, commerce, and riches, for the declining Hanseatics, whose threatenings, therefore, the Queen disregarded; and Werdenhagen, their historian, a few years after this, acknowledges, that the English, in all those respects, as also in the bravery of their commanders and sailors, excelled the Hanse Towns ; and Hamburg, though a potent Hanse Town, which had formerly rejected the English merchants, now began to court their residence, in consequence of which, they [the English merchants] removed from Emden to Hamburg, whence they soon extended their commerce into Saxony, Prussia, and Russia, which gave great umbrage to the Danes."- "Annals of Commerce," ii., p. 150 (see 1578 ).

1572. The League was again in dispute. This time it arose out of a peace concluded between the city of Lubeck and King John of Sweden, after a war of eight years; one of the articles of which was, that the Lubeckers might freely trade with Livonian Narva, then in the hands of Russia. This the Swedish monarch afterwards disregarded, he being himself at war with Russia. A Grand Assembly of the Deputies of the Hanse Towns was hereupon convened; but it does not appear that any effectual measures were devised or applied. This indicates the declining power of the League.

I578. It had been the manifest policy of the Queen to keep the Hanseatics in suspense regarding the renewal of their privileges, until her own subjects had felt their way in respect to the increase of their foreign trade and shippingand, as we have seen, the progress in these respects was most satisfactory. The League, finding it could not shake her firmness, applied to the Emperor Rodolph II., as their sovereign, urging the necessity of compelling her to reinstate them in their immunities, and particularly that of paying only the ancient custom of I per cent. The Queen replied to that Emperor's remonstrances, that she had done the 
Hanseatics no kind of wrong, having treated them on the same footing in which she had found them at her accession to the crown; it was her sister who had abolished the old duty, and laid on that now subsisting.

This answer was deemed to be far from satisfactory, and led to retaliatory measures on each side. The Hanseatics growing louder in their complaints all over Germany, they at length issued a prohibition of the English merchants to reside any longer in Hamburg; whereupon the Queen published a declaration, annulling all the ancient immunities of the League in England, and only allowing them the same commercial privileges that other foreigners enjoyed. Soon after, she prohibited all foreigners, and particularly the Hanse or Steelyard merchants by name, from exporting English wool. This prohibition was said to be greatly owing to the industrious Protestant Netherlanders, lately driven out by the Spanish governors, and settled in England, having advised the prohibition of unmanufactured wool. It was a great blow to the Hanseatics.

1579. A general assembly of the Hanse delegates assembled at Lunenburg this year, laid a duty of $7 \frac{3}{4}$ per cent. on all goods imported into their territories by Englishmen, or exported by them; whereupon Queen Elizabeth laid a like duty of $7 \frac{3}{4}$ per cent. on all merchandise imported or exported by the German Steelyard merchants. Thus matters became more and more embroiled between England and the German Hanse Towns, "the magnanimous Queen (says Macpherson) being firmly determined never to yield to their unreasonable demands."

1587. About this time the Queen granted to the Steelyard merchants the same commercial privileges and immunities, in point of customs on commerce, as were enjoyed by her own natural-born subjects; provided, however, that her English merchants at Hamburg were equally well treated, which yet did not give them entire content. In the meantime, the Queen being at war with Spain, gave the Hanse Towns due notice not to carry into Spain, Portugal, nor Italy, provisions, 
naval stores, or implements of war, for the King of Spain's use, under forfeiture thereof, and even of corporal punishment.

1589. The final breach between Elizabeth and the Hanse Towns arose out of the events of this year, in the following shape. The Queen determined to avenge the Armada of last year by a return cruise of private adventurers, led and protected by six vessels of the Royal Navy, and some Dutch ships. The number of ships so collected is stated to have been 146 . In the Tagus, this expedition took some 60 hulks (or Fly-boats) of the German Hanse Towns, laden with wheat and warlike stores, to furnish the new armada against England. The cargoes were retained, but the ships were released. These ships had sailed from their ports by way of the North Sea, and the West Coast of Ireland, and so had escaped observation, and earlier capture. The Queen having forewarned the Hanse Towns in 1587 (as we haye seen) against sending any such stores, the capture was quite legal, but it involved several years of correspondence and remonstrance from some of the Towns of the Empire, and of Poland and Dantzic - they being deeply interested in this seizure. In the end it led to a final breach between England and the Hanse Towns, as will be seen.

1591. An assemblage of some of the principal members of the League took place at Lubeck this year. Its immediate object was to remonstrate with Elizabeth for the course she had taken. They embodied a style of indignation, reproach and menace, in their communications to which the Queen answered: that she was willing to attribute their want of respect to their amanuensis or secretary, but that she set no sort of value upon their hostile intentions. The Hanseatics then set to work in another manner, not indeed new to them, by depreciating the company of English Merchant Adventurers. Such an attempt being made at Elbing, the Elbingers wrote a respectful letter to the Queen informing her of what had occurred, and of their intention to abide by the decision of the King and Diet of Poland; but in the meantime they would, under Her Majesty's protection 
and authority, go on as their inclination led them in favour of her merchants. And King Sigismund of Poland, in a respectful letter to the Queen, also declared his approbation of the English Merchant Adventurers residing at Elbing, or anywhere in Poland.

This year, too, there was compiled a code of laws for the regulation of the maritime affairs of the League. The deputies called to their aid representatives from the free and maritime towns of the German Empire, whether in the Confederation or not. The League had first used the Laws of Oleron, and afterwards those of Wisby. It now found a code adapted to its own circumstances desirable. It is a remarkable feature of this Code that it makes no reference whatever to marine insurance, other than in its old form of Bottomry. The reason for this may well be, that the maritime operations of the Confederation were so large that the League undertook its own maritime risks, like some of the great steam shipping companies of the present day. Mr. Reddie thinks it possible that "its influential leaders may have seen in the transactions of insurance only a great innovation, of which the advantages were still not sufficiently developed to admit of any attempt to subject them to positive rules, and of which the conditions behoved in each case to be regulated by special contract."

1594. The Emperor Rodolph II. having written to the Queen in the preceding year respecting the grievances of the Hanse Towns-therein styled the "Maritime Cities of the Baltic League"-and to which position they were now indeed fast reverting, Elizabeth sent a special envoy to the Emperor to vindicate her conduct in the matter. He explained that the ancient privileges which the League formerly had in England, because of their abuse of them, and in consideration that they were incompatible with the good government of the realm, had been abrogated by Edward VI., yet the Queen had, in the beginning of her reign, granted them to trade on the same terms as her own subjects, and so on, as I have already set forth. He urged that in all kingdoms some old usages and privileges are by change of circumstances taken 
away, particularly for the abuse of them. The Hanses had no cause to complain of England, but of themselves!

1595. This year the Lord Mayor of London received from the Lords of the Council a letter, dated 5 th October, directing him to appoint some of the Aldermen of the City to consult with the Alderman of the Steelyard with referenceto the saltpetre men appointed to dig and make saltpetre in their house.

The Lord Mayor replied on the following day that certain Aldermen and others, with the Lieutenant of the Ordnance had viewed the rooms within the Steelyard, where the saltpetre men were to dig, under warrant for saltpetre, and had delivered a certificate enclosed. They found by the complaints of the citizens that the said saltpetre men entered into houses, shops, and warehouses of poor artificers within the city to dig for saltpetre to the great hindrance of their trade. $\mathrm{He}$, therefore, requested that they might be admonished and charged to use more discretion and moderation in the execution of their warrant.*-Remembrancia, 214-15 (see again 1613 ).

* There is a remarkable history concerning this question of saltpetre. Before the discovery and importation of Indian nitre, saltpetre was manufactured from earth impregnated with animal matter, and being the chief ingredient of gunpowder, was claimed by the Government, and in most countries became a State monopoly. Patents for making saltpetre were specially exempted in 1624 from the statute against monopolies (2I Jac. I. c. iii. s. Io), and the saltpetre man was empowered to break open all premises, and to dig up the floors of stables, and even dwelling-houses. This privilege was very scrupulously exercised, an instance of which may be seen in Archbishop Laud's "Diary" (1624, Dec. I3th), that the "Saltpetre men had digged in the Colledge Church of Brecknock for his work [material] bearing too bold upon his commission." Charles I., in 1625, and again in 1664, commanded by Proclamation, that no dovehouse or stable should be paved, but should lie open for the growth of saltpetre, and that none should presume to hinder any saltpetre man from digging where he thought proper. The vexation and oppression of the King's subjects by the saltpetre men is especially mentioned in the famous "Remonstrance of the State of the Kingdom" in 1641 , and no effectual remedy was applied until 1656 , when it was enacted that no saltpetre man should dig within any houses or lands without previously obtaining the leave of the owner. This vexatious prerogative of the Crown was maintained in France until 1778, and was not abolished in Prussia until 1798.-Waters's Parish Registers, p. 37. 


\section{EXPULSION FROM ENGLAND.}

I 597. The merchants of the League still pursued their later policy of opposing the operations of the English Merchant Adventurers in Germany, in the belief that the Queen would gladly restore the ancient privileges of the Hanse merchants in England, in order to protect those of the company named. Herein they greatly erred, for such was not the policy of the Crown. The Queen, as a matter of decorum, demanded a revocation of the Imperial edict, by which the comptoir of the English company was to be excluded from Staden, and the merchants from other parts of Germany. She then, without further delay, directed a Commission to the Mayor and Sheriffs of London to shut up the house inhabited by the merchants of the Hanse Towns in the Steelyard, London. And, moreover, ordered all the Germans there, and everywhere else throughout England, to quit her dominions on the very day on which the English were obliged to leave Staden!

I601. At the beginning of this century the merchants of Hamburg and other of the Hanse Towns made regular annual voyages up the Mediterranean as far as Venice, to their great profit. But Amsterdam was now fast absorbing this trade, and finally monopolized it. Formerly the League had traded to Florence, Genoa, and Messina for silk, in exchange for their grain ; and the ships of Lubeck, Wismar, and Straelsund then also used to frequent the ports of Spain, till supplanted therein also by the more dexterous Hollanders.

Wheeler, first the secretary, then the advocate, and finally historian of the English Merchant Adventurers' Companywhich company unquestionably did much to hasten the downfall of the League-became, as a matter of course, the great antagonist of the Hanseatics. In his "Commerce," written this year, he makes no attempt to conceal his pleasure that the power and strength of the League were so much decayed that the State need not greatly fear it. For the causes which made the Hanse Towns of estimation and account in old times were (he truly says) the multitude of their ships and sea trade, whereby they stored all (European) countries with 
flax, hemp, linen, iron, copper, grain, and naval stores, etc., and served princes with their large and stout ships in time of war. It would be found they had now lost these advantages. If her majesty should forbid all trade into Spain, as other princes had done, further advantages to the League would be lost ; for that trade was now its chiefest support. "Besides of the seventy-two Confederate Hanse Towns so much vaunted of, what remains almost but the report? And those which remain, and appear by their deputies when there is any assembly, are they able, but with much ado, to bring up the charges and contributions, \&c., for the defence and maintenance of their League, privileges, and trade, in foreign parts and at home? Surely no! for most of their teeth are out, and the rest but loose!" etc.

It is curious to note the influence of the disruption of the League upon certain cities which had belonged to the confederation. Hamburg, which appears to have been one of the first towns which took any steps in the direction of the formation of the League, but which in the days of its power appeared to be treated with coolness-was this through the jealousy of Lubeck ?-Hamburg now rose to a greater point of importance than it had ever occupied previously, and at the close of this century was ranked next to London and Amsterdam. It had still continued to increase. Lubeck, it was evident, owed much of its importance to the influence of the League; and declined rapidly on its dissolution. Bremen the same. Dantzic became rapidly advanced in importance. Many of the Baltic cities lost their importance almost entirely. Trade now followed, in fact, its natural and unrestricted channels. First England, and then Holland, gained most by the change.

\section{ATTEMPTED RESUSCITATION.}

I604. An Assembly of Hanseatic Deputies now appointed a solemn Embassy to foreign nations for the renewal of their mercantile privileges, in the name of the cities of Lubeck, Dantzic, Cologne, Hamburg, and Bremen. They first addressed the English monarch, King James, who because they 
brought no letters from the Emperor of Germany, soon dismissed them with the following answer from his Privy Council:-That as their privileges were heretofore adjudged to be forfeited, and thereupon resumed by the King's predecessors, in respect of the breach of conditions on their part, so it can no way stand with the good of the State to restore them again to the said privileges." And with this answer they departed, nothing contented.

The Hanseatics went thence to the Court of France, where they met with abundance of good words, but nothing else ; and then they went to the Court of Spain, where, probably for the Emperor's sake, they had some success.-Macpherson, ii.,p.240.

I612. The Baltic Hanse Towns were greatly oppressed in their commerce by the additional dues which Denmark (again at war with Sweden) had imposed upon all ships passing the Sound. The Lubeckers made a league with Holland for the mutual protection of their commerce and navigation-determining to send an armed force to the Sound for that end. Other of the Hanse Towns soon came into the arrangement. The King of Denmark now claimed that he was Lord of the Baltic Sea. This circumstance (as affecting the growing commerce of England) probably induced King James to join with Holland and the Hanse Towns in a complaint; and the tolls were now reduced to the same rate as before the present war. It certainly was a remarkable incident to find England so soon operating in conjunction with the League; but as we have before remarked, it is impossible to predict the shape or direction political or commercial interests may assume. We must see what followed.

1613. In order to guard against future encroachments by Denmark the Dutch this year contracted an alliance with the Hanse Towns in general-and a more special one with Lubeck two years later (1615), wherein they agreed to stand by each other against all impositions. Macpherson remarks hereon :

"This effort of the declining Hanse Towns to draw the Dutch into a confederacy with them for the freedom of commerce, did, by 
the powerful conjunction of England, produce the desired effect. Yet, in general, it was unlikely that any durable confederacy (and much less an union, as some then proposed) could take place between the Dutch and so great a number of widely dispersed towns, with interests almost as different as their situations ; overawed, too, by the greater potentates near them, since they have become so strong in shipping. Such an union, therefore, could not be advantageous to the Dutch, whose aim always was to gain ground everywhere in commerce, and who now for more than a century have engrossed the greatest part of the commerce of the Baltic, and thereby have rendered most of the Hanseatic powers on that sea as empty of good shipping as their exchanges are now of rich merchants."

It turned out in truth that this present effort was but a parting flicker; for Werdenhagen records that "about this time the Swedes treated as enemies all such merchants as did not take out licences from their king for liberty to trade thither; so that the Easterling Hanse Towns, being pressed with difficulties on every side, were obliged to relinquish a great part of their ancient commerce, which gradually brought on their great present declension." This was written in 1630 .

The saltpetre question, which had come up in 1595, was again brought to the front this year in the following manner. The Earl of Worcester addressed a letter to the Lord Mayor (date "Sept.") informing him that the King had by Letters Patent committed to his charge the making of Saltpetre and Gunpowder for the use of his majesty within his dominions, with power to appoint deputies, and requiring the Lord Mayor and Aldermen to prevent any persons digging for, or making, Saltpetre within the City and Liberties, except John Evelyn, Esq., of Godstone, Surrey, his factor, servants, etc., to aid him in the performance of the business, and in the event of any other person being found working to require them to cease, taking bond from them either to do so, or appear before the Privy Council.* This was evidently a curtailment of the privileges of the League in England.

* A licence was granted to the Earl of Worcester for the sole making of Saltpetre and Gunpowder in England and Ireland for twenty-one 
1622. The progress of the English Russian, the East India, and the Merchant Adventurers' Companies, and their building "many stout ships," had further interfered with the commerce of the Hanse Towns; and those on the southern shores of the Baltic were reported as greatly decayed at this date.

1630. This year Gustavus Adolphus, King of Sweden, having entered Germany with an army, occasioned much damage to the commerce of the Hanse Towns by the devastations committed by his troops. In that King's manifesto he accuses the Imperialists "of forbidding his merchants all freedom of commerce; seizing on their merchandise, and confiscating their ships, under the pretence of establishing a general commerce at Lubeck for the Hanse Towns; which, in effect, was driving the Swedes from the whole commerce of the Baltic, and erecting a naval force at the expense of his merchants, in order freely to ravage and pirate in that sea; having newly created an unheard-of dignity of a General of the Seas for that purpose, and possessed themselves of the forts and fortified places of Mecklenburg and Pomerania: fortifying the port of the Free Hanseatic City of Straelsund for a receptacle and retreat to their pirates." This was probably an overdrawn view; but it at least goes to show that the Baltic portion of the League was "dying hard."

THE END.

It is stated that in consequence of this manifesto, a General Diet was this year convened at Lubeck, but that none of the cities sent their representatives, except to notify the resolution which they had taken to abandon it. This statement

years, revocable at pleasure, dated May 8, 1607. An Indenture was signed by the King and the Earl of Worcester, the latter agreeing to deliver eighty lasts of gunpowder per annum at the Tower of London, at $8 \mathrm{~d}$. per pound, and as much more as might be required at $9 \mathrm{~d}$., dated May 8, 1607. See Calendar of State Papers, 1603-10. Another grant was made to the Earl, with some alterations from his former commission in 1616 ; of which he gave notice to. the Lord Mayor in a letter dated "Worcester House, June 13, 1617." Remembrancia, pp. 218, 219. 
I take upon the authority of Mr. Reddie ("Historical View of the Law of Maritime Commerce, I84I"), who does not give any authority for it; but his name will be deemed sufficient by all who know his works. He adds :-

This dissolution of the confederacy, however, proved so far beneficial to some of its parts. The cities of Hamburg and Lubeck, in particular, gained in opulence what they had lost in power. Finding themselves no longer at the head of an ambitious League, which had enabled them to exercise a kind of commercial despotism over their neighbours, they adopted milder maxims of trade; and contenting themselves with the peaceful interchange of commodities, preserved, with a recent temporary interruption, their liberties and political independence.

I647. It seems probable that the alliance formed between various cities of the League and Holland in 1612 , continued all through the long and sanguinary wars between Austria on the one side, and France and Sweden on the other, and the less tardy warfare between the United Provinces of the Netherlands on the one side and Spain on the other. The famous Treaty of Westphalia, concluded this year, terminated these contentions, and pacified for the moment the great potentates of Europe-England (who was not a party to the treaty) perhaps alone excepted. It was stipulated that the Hanse Towns should enjoy all the same rights, privileges, etc., in the dominions of Spain, which by this treaty were or should be granted to the subjects of the States-General ; and reciprocally the subjects of the States-General were to enjoy the same privileges, etc., in Spain as the Hanseatics : whether for established consultation in the capital forts of Spain, or elsewhere, as should be needful, or for the freedom of their merchants, factors, etc., and in like sort as the Hanse Towns had formerly enjoyed, or should hereafter obtain for the security of their navigation and commerce! Here was the only spirit still retained. It was battling for the shadow only: the substance was already gone! From that hour I trace no more, even a mention of the League, in the great 
commercial history of Europe. It had played its part ; it was now dead; but will never be forgotten!

I confess I cannot write these last words without a feeling of sorrow, of real regret, at the mutability of worldly affairs, as evinced in the preceding history. Here is a combination which had played a most important part, not only in the commercial progress, but more or less in the political supremacy of Europe for four centuries-a longer period, I believe I am right in saying, than is claimed for any other known combination, commercial or political. It had, during the greater portion of that period, been a most potent power. It had, without much doubt, subsidized our kings in earlier times. Our English Henry III. indeed had incorporated its representatives in England as a Trading Guild, in acknowledgment of the assistance of the League in his naval wars, and also for money lent him! The French Kings, Louis XI., Charles VIII., Louis XII., and Francis I. had bestowed great privileges on it. The Emperor Charles V. had availed himself of its bounty. It had aided in creating, as in dethroning, many Kings and Princes ; and the only monument of its own greatness lives in the memories of the few who have made its real history a matter of personal study!

\section{NOTE.}

I think it better to add the enactment of 1523 , which I have referred to under date $15 \circ 3$, but have not included in the text.

1523. By I4 \& I 5 Hen. VIII. c. 29, "per M'catoribz de Hansa," it was enacted as follows :-

"Provyded always that none Acte, Statute, or Ordenaunce had made or to be made in this present Parliament in any manner of wyse extend or be prejudiciall or hurtfull unto the merchauntes of the Hanse of Almayn or to any of them havyng the House withyn the Citie of London, commonly called Guyldhalda Theotonicorum, by what name or names they or any of them be named or called: any Acte, Statutes or Ordenaunces made or to be made to the contrary in anywise notwithstondying."

The Acts against which this is intended to give exemption were 
probably the following, but many like exemptions will be found in various statutes :-

Cha. I. The Act concernyng the conveying, transportyng and cariyng of Brode Whyte Wollen Clothes out of this Realme.

Cha. IV. An Acte for payment of Custome.

The following additional notes as to the internal regulations of the League will help to complete our outline.

The discipline at the Factories was of the strictest nature, and the ordeals the acolyte merchants underwent would be deemed incredible, if they were not vouched on authority. The initiations were termed "plays," and were more than thirty in number, but the three principal ones were smoke, water, and the scourge; these were exercised with such severity that the candidates sometimes sank under the operation.

In London, as in the other Hanseatic comptoirs, all the meals were taken at a common table, but these merchants lived well, and ate and drank the best of everything the world could afford. The government of the Steelyard was through a council of twelve members-a master or alderman, two assessors, and nine common councilmen, elected annually. This was in fact an independent civil government, not subject to the common law of England. Every New Year's eve there was a general meeting for the transaction of business and election of officers. The oath of installation was as follows :-

"We promise and swear to keep and uphold, all and every, the rights and privileges of the Hanse merchants in England, as well as to obey the laws and regulations made for them, all to the best of our abilities ; and we promise and swear to deal justly towards every one, whether powerful or humble, rich or poor, so help us God and His saints."

It would seem but reasonable that a society which required such an oath, and officers who subscribed to it, must have been honourable in nature and intentions ; and, indeed, it must be admitted to the credit of these merchants, that their dealings were honorable to a degree which would shame much of the business of the present day. They endeavoured to monopolize trade, as they felt to be their duty towards their principals, and they stood stoutly for rights and privileges which, by long use, they had considered as absolutely vested in their League. They did not appreciate the fact that they were absorbing rights and business which belonged to the nation at large, and in this feeling they were not one whit worse than many of their com11 


\section{TRANSACTIONS OF THE ROYAL HISTORICAL SOCIETY.}

mercial descendants, who do not monopolize trade simply because they cannot.-Vide Exchange and Review.

As I have already said, the enactments of the League attest the importance in which it held fidelity in the execution of mercantile engagements, without which there cannot exist any true or genuine credit. He who, having borrowed in one city of the confederacy, did not pay his debt, or who, having lent money upon pledges in security, carried off what his debtor had thus entrusted to him, forfeited the status of a Hanseatic citizen. A debtor, excluded from one of the confederated cities on account of his debts, could not find an asylum in any other of these cities. The bankrupt whose flight had been advertised, with a description of his person, behoved to be arrested wherever he could be found, and, if fraudulent, exposed in public, loaded with irons, if not punished with death!

The ordinances of the League also contain numerous regulations relative to fidelity in weights and measures, and the quality of different kinds of merchandise, relative to the capacity and exterior marks of casks in which were contained certain commodities that were purchased and re-sold by wholesale; and against the debasement of coined money. Some also related to the good order of corporations of tradesmen, to apprenticeships, and to the obligations of agents and commission men (prapositi) to render accounts to their principals or constituents.

Nor are we surprised to find special regulations for the commerce of salt; prohibitions against the sale of herrings not yet caught, of grain not yet reaped, and of cloth not yet woven; against the exportation of cloth to be dyed in another place than that in which it was woven; against the exportation of gold and silver to be wrought and manufactured in a foreign country; against selling cloths with a false dye, or perfume of which the quality was adulterated!

There is reason to believe that the contract of exchanges was practised amongst the inhabitants of the Hanse Towns. - Vide Reddie's Maritime Commerce, p. 256-7.

In the great "staplehouses" in London, as well as in the smaller ones at Boston and Lynn, there were stored immense quantities of raw products, principally wool, tin, and hides-which were exported from England-as also numerous articles received in exchange from abroad, enumerated by Stow, as "wheat, rye, and other grain; cables, ropes, masts, pitch, tar, flax, hemp, linen cloth waistcoats, wax, steel, and other profitable merchandise." 